\title{
PENGEMBANGAN APLIKASI PENGELOLAAN KARYA ILMIAH MAHASISWA DAN DOSEN BERBASIS TEKNOLOGI WEB
}

\author{
K. Setemen ${ }^{1}$, L. J. E. Dewi ${ }^{2}$, N. W. Marti ${ }^{3}$ \\ 1, 2, 3 Jurusan Manajemen Informatika, Fakultas Teknik \& Kejuruan \\ Universitas Pendidikan Ganesha \\ Singaraja, Indonesia
}

e-mail:km_setemen@yahoo.com; luhdewi@yahoo.com; wayanmarti@yahoo.com

\begin{abstract}
Abstrak
Tujuan penelitian ini adalah mengembangkan sebuah aplikasi yang digunakan untuk pengelolaan karya akademik mahasiswa dan dosen berbasis teknologi web. Aplikasi ini dikembangkan menggunakan CMS (Content Management System) Ganesha Digital Library Versi 4.2 (GDL 4.2) yang dibuat oleh KMRG ITB. Rancangan penelitian ini adalah rancangan penelitian dan pengembangan (R\&D). Penelitian ini melibatkan studi pendahuluan yang telah dilakukan dalam pengembangan rancangan sistem, tahap pengembangan dan penyempurnaan serta uji lapangan validasi produk yang dihasilkan, dan desiminasi internal produk untuk menentukan tingkat apresiasi dan efektifitas sistem yang dibangun. Hasil akhir penelitian yang dikembangkan berupa sistem berbasis teknologi web. Aplikasi yang telah dikembangkan mampu menangani masalah pengelolaan karya akademik mahasiswa dan dosen. Adapun klasifikasi dari karya akademik mahasiswa dan dosen tersebut antara lain adalah: laporan PKM, laporan PKL, laporan tugas akhir, laporan skripsi, tesis, disertasi, makalah dalam prosiding, artikel dalam jurnal, proposal penelitian dan laporan penelitian.
\end{abstract}

Kata kunci: pangkalan data, CMS, karya akademik, web

\begin{abstract}
The purpose of this research is to develop an application that is used for the management of students and lecturer academic work based on web technology. This application was developed using a CMS (Content Management System) Ganesha Digital Library Version 4.2 (GDL 4.2) made by KMRG ITB. The design of this research is research and development $(R \& D)$. This study involves the preliminary studies that have been done in the development of system design, development and improvement and validation field test the product, and internal dissemination of products to determine the level of appreciation and effectiveness of the system. The final products of this research is a system based on web technology. Applications that have been developed capable of handling the management of students and lecturer academic work. The classification of the of students and lecturer academic work is: a report of PKM, PKL report, final report of students, thesis report, dissertations report, papers in proceedings, journal articles, proposals and research reports.
\end{abstract}

Keywords: database, CMS, academic work, web 


\section{PENDAHULUAN}

Tugas dosen selain sebagai pengajar adalah melaksanakan penelitian dan pengabdian pada masyarakat. Hasil akhir dari penelitian dan pengabdian masyarakat dari dosen-dosen adalah berupa artikel ilmiah yang dipublikasikan secara nasional maupun internasional dan ada pula dalam bentuk buku teks yang di terbitkan. Hasil karya dosen ini belum dimanfaatkan secara maksimal untuk berbagai keperluan diantaranya adalah sebagai rujukan untuk perbaikan proses pembelajaran, sebagai referensi bagi dosen-dosen yang lain untuk mengembangkan dan memperbaiki penelitian yang ada, atau referensi bagi mahasiswa dalam pembuatan tugas akhir atau skripsi. Sampai saat ini, pengarsipan terkait dengan hasil-hasil penelitian dosen masih dilakukan secara manual, artinya kumpulan artikel ilmiah tersebut disimpan dalam bentuk fisik (hard copy) yang tersedia di perpustakaan pusat atau perpustakaan jurusan.

Perkembangan Teknologi Informasi
dan Komunikasi (TIK) dewasa ini memberikan dampak yang sangat signifikan khususnya terhadap dunia pendidikan. Universitas Pendidikan Ganesha (UNDIKSHA) sebagai salah satu instansi pendidikan telah berusaha secara optimal untuk mengimplementasikan TIK ke dalam lingkungan kampus. Adapun tujuan yang ingin dicapai adalah untuk meningkatkan kualitas dan layanan pendidikan terhadap seluruh civitas akademika.

Berbagai perguruan tinggi yang sudah maju khususnya di Indonesia telah melakukan upaya untuk memanfaatkan TIK ke dalam berbagai proses administrasi dan pengelolaan informasi di kampus, yang di lihat sebagai enabling technology. Khusus untuk pengelolaan karya imiah beberapa perguruan tinggi telah melakukan proses pengelolaan data karya ilmiah dengan memanfaatkan TIK, diantaranya adalah Universitas Indonesia dengan nama sistem lontar (Library Automation and Digital Archive) tersedia di alamat http://lontar.cs.ui.ac.id/Lontar/opac/themes/n g/. Institut Teknologi Sepuluh Nopember Surabaya, dengan nama sistem ITS Digital Repository tersedia di alamat http://digilib.its.ac.id. Universitas Gadjah Mada dengan nama sistem Digilib Universitas Gadjah Mada tersedia di alamat http://perpustakaan.tp.ugm.ac.id/digilib/.

Dari uraian di atas memberikan gambaran bahwa perlunya sistem yang memanfaatkan TIK dalam proses pengelolaan dan manajemen sumber informasi agar dapat memberikan akses yang optimal terhadap seluruh civitas akademika, sehingga dapat dijadikan sebagai bahan pustaka atau referensi untuk kepentingan yang lebih luas. Untuk itu melalui penelitian ini telah dikembangkan sebuah aplikasi yang digunakan untuk pengelolaan karya akademik mahasiswa dan dosen berbasis teknologi web. Aplikasi ini dikembangkan menggunakan CMS (Content Management System) Ganesha Digital Library Versi 4.2 (GDL 4.2) yang dibuat oleh KMRG ITB. Aplikasi ini dimodifikasi sedemikian rupa agar dapat disesuaikan dengan kebutuhan terkait dengan pengelolaan karya akademik mahasiswa dan dosen, yang sementara ini data-data yang sudah dimasukkan ke dalam sistem adalah data yang ada pada Jurusan Manajemen Informatika. Aplikasi yang telah dikembangkan mampu menangani masalah pengelolaan karya akademik mahasiswa dan dosen. Adapun klasifikasi dari karya akademik mahasiswa dan dosen tersebut antara lain adalah: laporan PKM, laporan 
PKL, laporan tugas akhir, laporan skripsi, tesis, disertasi, makalah dalam prosiding, artikel dalam jurnal, proposal penelitian dan laporan penelitian.

Sejalan dengan visi dan misi Kementerian Pendidikan Nasional, yang kemudian diterjemahkan menjadi Standar Nasional Pendidikan (PP 19/2005) yang berisi delapan butir komponen standar penjaminan mutu, yaitu standar Isi, Proses, Kompetensi Lulusan, Pendidik dan Tenaga Kependidikan, Sarana dan Prasarana, Pengelolaan, Pembiayaan, dan Penilaian Pendidikan. Perguruan tinggi di Indonesia wajib mengadopsi kedelapan komponen standar ini sebagai komponen minimal dalam penjaminan mutu pendidikan dan dapat menambahkan komponen-komponen lain yang dianggap penting.

Proses penjaminan mutu perguruan tinggi perlu dijalankan melalui tahap-tahap yang terangkai dan didukung oleh sistem pangkalan data (basisdata) yang terintegrasi. Pangkalan data pada sistem ini harus berisi data yang lengkap/menyeluruh, akurat, up to date dan terklasifikasi dengan baik, sehingga dapat difungsikan sebagai sumber informasi dalam mengevaluasi komponen-komponen penjaminan mutu (Gunawan, dalam Veronica, 2006). Dengan memiliki sistem pangkalan data terintegrasi maka akan dapat dilakukan pengelolaan data yang lengkap dan up to date.

Universitas Pendidikan Ganesha (UNDIKSHA) sebagai salah satu instansi pendidikan telah berusaha secara optimal untuk mengintegrasikan pangkalan data yang ada dengan memanfaatkan kemajuan teknologi informasi yang ada saat ini. Adapun tujuan yang ingin dicapai adalah untuk meningkatkan kualitas dan layanan pendidikan terhadap seluruh civitas akademika. Akan tetapi, pangkalan data yang dikelola dan dipusatkan pada Unit Pusat Komputer UNDIKSHA masih belum mampu menangani secara penuh data-data yang ada, salah satunya adalah terkait dengan karya akademik mahasiswa dan dosen.

Beberapa penelitian sebelumnya tentang sistem pangkalan data yang identik dengan penelitian ini telah dilakukan oleh beberapa peneliti dengan kasus dan sistem yang digunakan berbeda-beda. Depri Pramana (2010), telah mengembangkan sistem untuk menangani pencatatan daftar laporan PKL dan Tugas Akhir mahasiswa di Jurusan Manajemen Informatika. Tri Susilowati (2010), telah mengembangkan ELibrary berbasis CRM di STMIK Pringsewu. Sistem e-library ini menggunakan rantai nilai yanng ada di Customer Relationship Management (CRM) yaitu acquire, enhance, dan retains dalam merancang fitur-fitur yang ada. Fitur-fitur yang ditawarkan diantaranya adalah: pustaka digital yang dapat diunduh oleh semua anggota, pendaftaran angota secara online, catalog digital online, dan lain-lain. Arif B. Putra, dkk. (2010), telah mengembangkan Sistem Informasi Jurnal IImiah Online. Sistem yang dikembangkan merupakan sistem yang berisi tentang jurnal-jurnal ilmiah yang bisa dimanfaatkan oleh pihak luar melalui website. Rizal Fathoni Aji, (2010), mengembangkan garuda rujukan digital, yang merupakan sistem yang menyediakan daftar rujukan digital untuk karya ilmiah. Model arsitektur yang dibuat digunakan untuk menggabungkan data-data perpustakaan dari jenis sumber informasi.

TIK merupakan "bahan bakar" ekonomi digital atau ekonomi berbasis pengetahuan. Kita dapat menyebutnya sebagai bahan bakar mengingat perannya yang sangat vital dalam kegiatan 
perkonomian masa kini. Kita bisa bayangkan bagaimana seandainya saat ini tidak digunakan Electronic Data Processing (EDP), Management Information System (MIS), Executive Information System (EIS), ataupun Expert System (ES) dalam kegiatan-kegiatan sehari-hari yang semakin kompleks (Hasibuan, 2007). Sedemikian pentingnya TIK tersebut, sehingga tidak ada alasan lagi dalam segala proses yang terjadi dalam kehidupan ini selayaknya sudah berbasis TIK.

\section{METODE}

Penelitian ini berupa rancangan penelitian dan pengembangan (R\&D). Penelitian ini melibatkan studi pendahuluan yang telah dilakukan dalam pengembangan rancangan sistem (Depri, 2010), tahap pengembangan dan penyempurnaan serta uji lapangan validasi produk yang dihasilkan, dan desiminasi internal produk untuk menentukan tingkat apresiasi dan efektifitas sistem yang dibangun. Produk yang dikembangkan berupa sistem berbasis teknologi web (hypertext) dalam bentuk pangkalan data tentang karya ilmiah mahasiswa dan dosen.

Pengembangan sistem ini di awali dengan peninjauan ke lapangan untuk mengetahui kondisi eksisting, serta rencana pengembangan. Pengumpulan data ini dilakukan dengan cara mengidentifikasi data karya ilmiah mahasiswa dan dosen yang ada di Jurusan. Semua data tersebut dikumpulkan, yang selanjutnya akan dipilah sesuai kebutuhan yang akan dilakukan pada tahap analisis. Tugas yang paling penting dalam proses ini adalah proses menemukan permasalahan dan menghasilkan alternatif pemecahan masalah. Dalam tahap ini akan dianalisis kebutuhan dari sistem yang akan dibuat. Analisis yang dimaksud adalah menentukan informasi-informasi apa saja yang akan dimasukan ke dalam sistem ini, sehingga benar-benar dapat bermanfaat bagi pengguna (mahasiswa, pegawai, dosen, staf yang lain serta masyarakat luas).

Selanjutnya adalah tahap desain atau perancangan, apabila tahapan analisis sistem sudah terpenuhi. Dalam tahap desain ini, juga akan di desain arsitektur dan infrastruktur TIK guna mendukung sistem pengelolaan karya ilmiah berbasis teknologi web yang akan dikembangkan. Dalam tahap ini juga akan dilakukan perancangan system yang meliputi, rancangan basis data, rancangan antar muka program, dan rancangan proses manipulasi data (input, delete, dan download), serta rancangan proses pencarian. Dari proses ini akan menghasilkan draft rancangan produk atau sistem. Selanjutnya sistem ini akan dilakukan uji pakar (expert judgement) untuk memperoleh masukan terkait dengan sistem yang telah dikembangkan. Berikutnya adalah penyempurnaan rancangan berdasarkan pertimbangan pakar, dan selanjutnya di lakukan uji operasional terbatas. Alur atau proses secara menyeluruh dari penelitian ini seperti tampak pada Gambar 1.

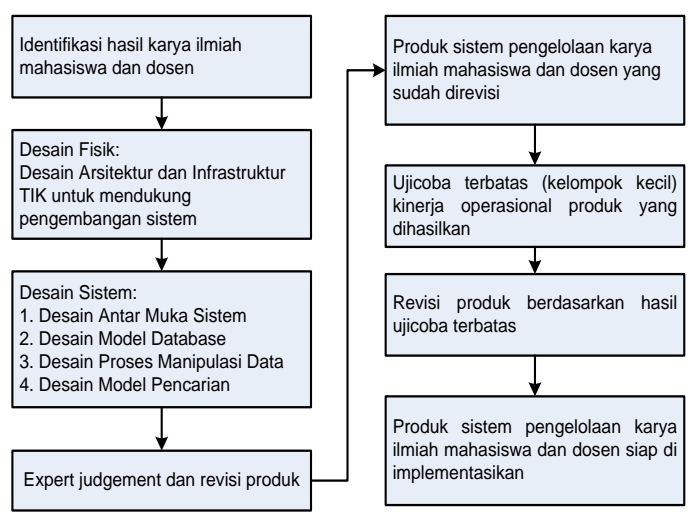

Gambar 3. Proses Kerja Penelitian Secara Menyeluruh 
Hasil akhir dari penelitian ini adalah sebuah perangkat lunak sistem yang menggunakan teknologi web sebagai bagian dari teknologi informasi dan komunikasi. Secara lebih eksplisit, hasil akhir dari penelitian ini adalah: 1) identifikasi hasi-hasil karya akademik mahasiswa dan dosen, yang dalam uji terbatas dilakukan di manajemen informatika, 2) desain arsitektur dan infrastruktur TIK untuk mendukung sistem, 3) model atau bentuk basis data yang digunakan, 4) model searching engine yang digunakan untuk memperoleh informasi yang cepat dan akurat.

\section{HASIL DAN PEMBAHASAN}

Tahap awal dari penelitian ini adalah melakukan identifikasi terhadap hasil karya ilmiah mahasiswa dan dosen yanga ada di Jurusan Manajemen Informatika. Hasil identifikasi selanjutnya diklasifikasikan agar memudahkan dalam proses pemasukan data dan pencarian yang berhubungan dengan data-data tersebut. Jenis-jenis data yang merupakan hasil identifikasi karya ilmiah mahasiswa dan dosen yang ada dan digunakan sebagai sampel inputan diklasifikasikan menjadi beberapa jenis, diantaranya adalah:

\section{a. Laporan PKM}

Laporan PKM (Program Kreativitas Mahasiswa) merupakan laporan yang dihasilkan oleh mahasiswa atau kelompok mahasiswa sebagai bagian dari kegiatan ilmiah mahasiswa. Laporan ini merupakan laporan hasil akhir kegiatan di bidang PKM yang terdiri dari PKM Pengabdian pada Masyarakat, Kewirausahaan, Gagasan Tertulis, dan PKM dalam bidang teknologi.

\section{b. Laporan PKL}

Laporan PKL (Praktik Kerja Lapangan) merupakan laporan kegiatan mahasiswa sebagai hasil dari proses pelaksanaan magang di industri.

\section{c. Laporan Tugas Akhir}

Laporan Tugas Akhir merupakan laporan yang dibuat oleh mahasiswa sebagai syarat kelulusan dari program diploma. Laporan ini merupakan karya original mahasiswa yang harus dibuat untuk melengkapi syarat-syarat kelulusan guna mencapai gelar ahli madya (A.Md).

\section{d. Skripsi}

Laporan skripsi hampir sama dengan Laporan Tugas Akhir, yaitu yang digunakan untuk untuk syarat kelulusan bagi program Sarjana.

\section{e. Tesis}

Laporan Tesis hamplr sama dengan Laporan Skripsi, yaitu yang digunakan untuk syarat kelulusan bagi mahasiswa program Magister.

\section{f. Disertasi}

Laporan Disertasi hampir sama dengan Laporan Tesis, yaitu yang digunakan untuk syarat kelulusan bagi mahasiswa program Doktor (Strata 3).

\section{g. Makalah dalam Prosiding}

Makalah dalam prosiding adalah makalah hasil pemikiran dosen maupun mahasiswa yang diseminarkan dalam seminar nasional maupun lokal, kemudian makalah tersebut diterbitkan dalam bentuk buku prosiding.

\section{h. Artikel dalam Jurnal}

Artikel dalam jurnal merupakan hasil karya mahasiswa maupun dosen yang diterbitkan dalam jurnal nasional baik yang terakreditasi maupun belum terakreditasi.

\section{i. Proposal Penelitian}

Proposal penelitian adalah hasil karya mahasiswa maupun dosen yang merupakan proposal usulan penelitian yang akan diajukan maupun yang sudah lolos dan didanai oleh lembaga maupun dikti. 


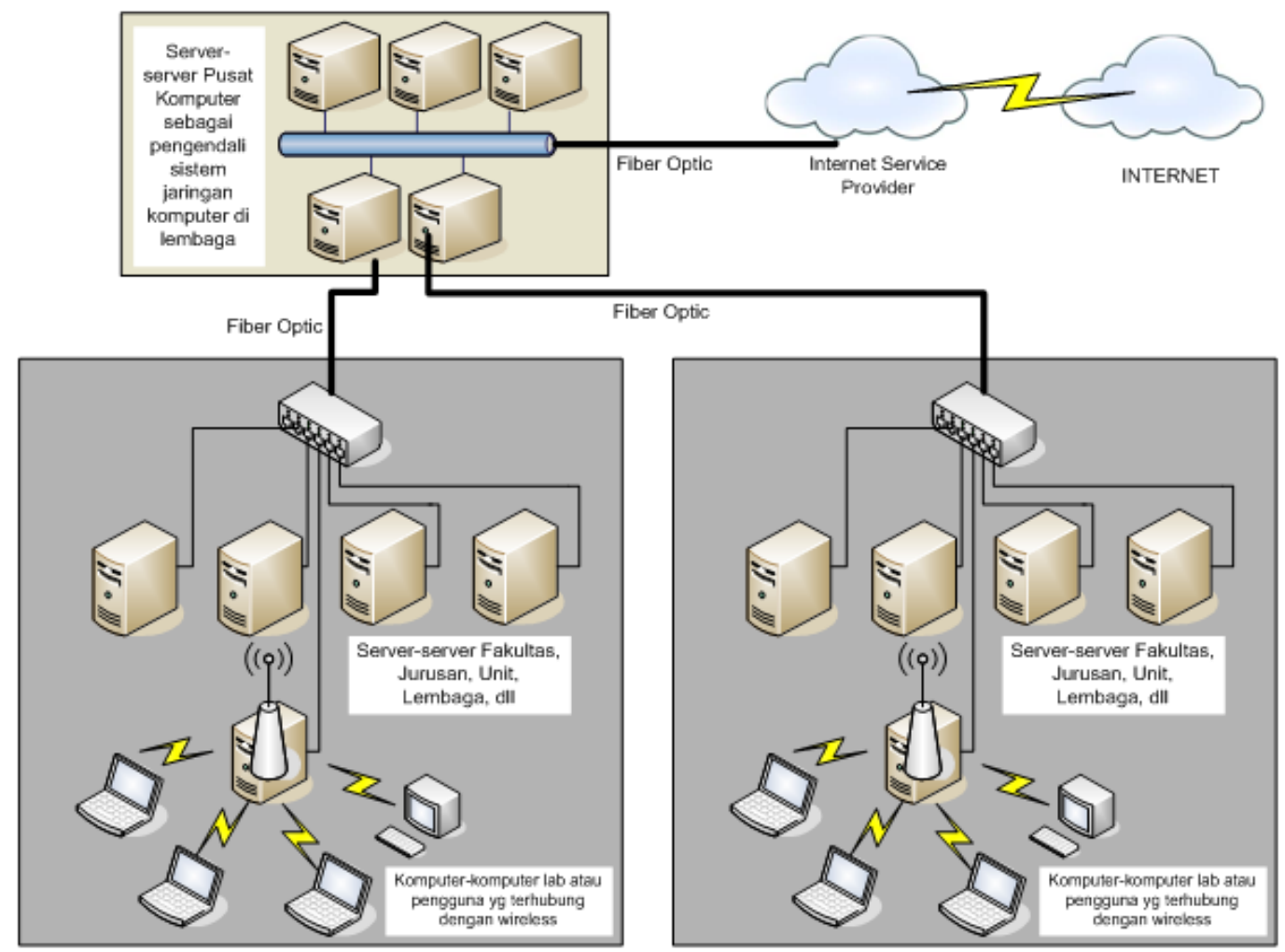

Gambar 2. Rancangan Infrastruktur Jaringan Lokal dan Global (Internet)

\section{j. Laporan Penelitian}

Laporan penelitian merupakan laporan hasil penelitian mahasiswa dan dosen yang telah dilakukan.

Dari jenis-jenis klasifikasi tersebut di atas, untuk sementara yang baru di inputkan sebagai sampel data adalah yang termasuk dalam jenis klasifikasi laporan pkl, tugas akhir, makalah dalam prosiding, dan artikel dalam jurnal. Karena keterbatasan waktu dan dengan alasan keamanan, maka untuk sementara file yang dimasukkan hanya berupa abstrak saja.

Guna mendukung aplikasi yang dibangun, maka harus dirancang infrastruktur yang memadai untuk aplikasi tersebut. Rancangan infrastruktur Teknologi Informasi dan Komunikasi (TIK) atau struktur jaringan lokal maupun global (internet), tampak seperti pada Gambar 2. 


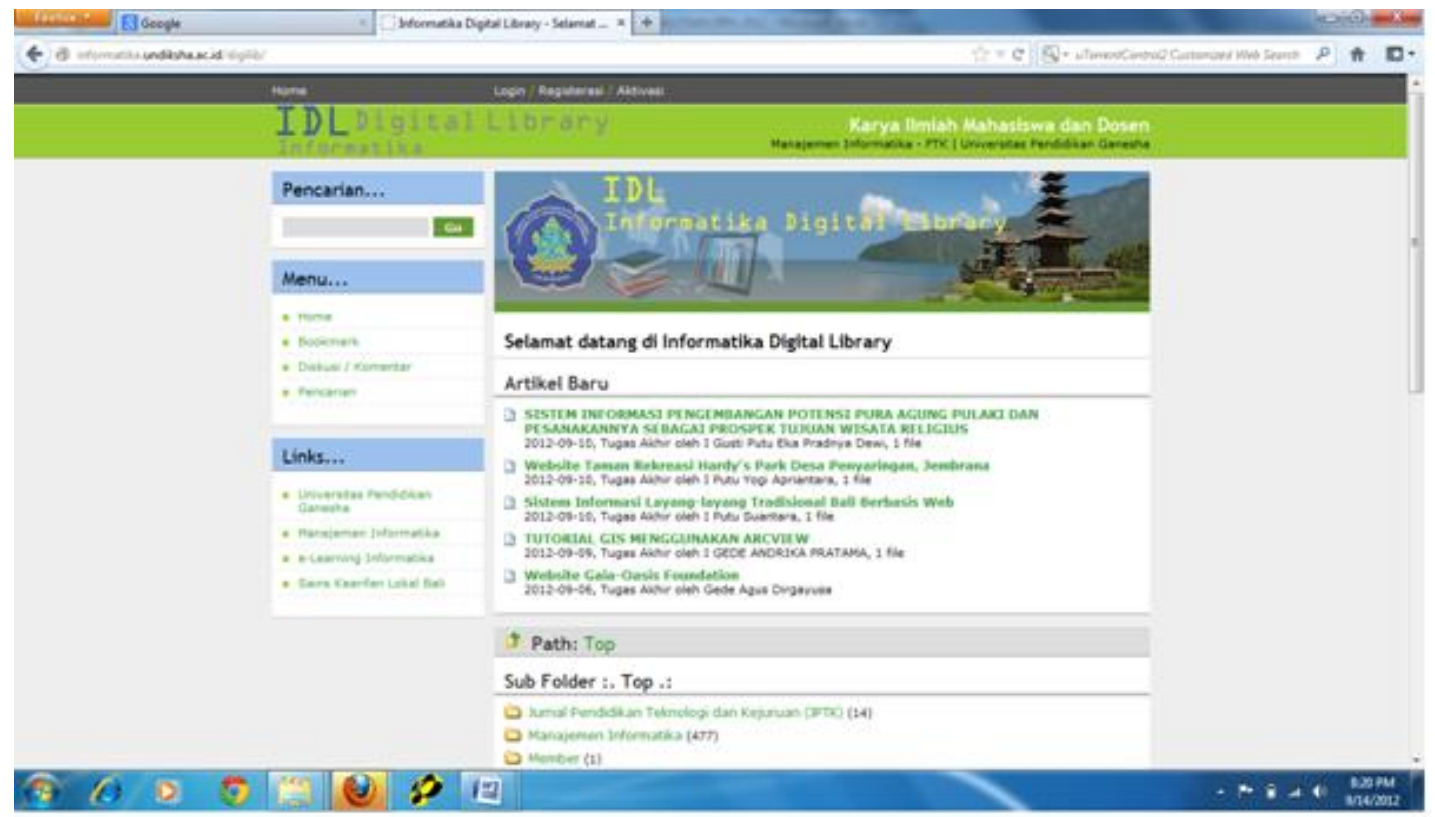

Gambar 3.Tampilan Halaman Utama dari Aplikasi

Hasil implementasi pengembangan sistem pengarsipan karya ilmiah mahasiswa dan dosen, disimpan pada web server Jurusan Manajemen Informatika yang sudah dapat diakses melalui internet alamat http://informatika.undiksha.ac.id/digilib maupun jaringan lokal di jurusan dengan menggunakan koneksi wireless melalui lablab yang ada di jurusan dengan alamat http://192.168.1.13/digilib. Tampilan antar muka dari halaman utama pada sistem ini tampak seperti pada Gambar 3.

Agar semua data-data yang dimasukkan ke dalam sistem dapat terekam sesuai kebutuhan, maka dalam pengembangan sistem ini dibuat rancangan basis data untuk merekam data-data tersebut. Rancangan Basis Data yang telah dikembangkan, dijabarkan dalam bentuk table-tabel yang memuat data yang akan dimasukkan ke dalam sistem. Berikut adalah beberapa tabel yang memuat informasi terkait dengan data yang disimpan. Tabel- tabel yang ditampilkan berikut ini merupakan tabel-tabel yang berhubungan langsung dengan data yang simpan, sementara tabeltabel yang digunakan untuk konfigirasi sistem sengaja tidak ditampilkan. Tabeltabel tersebut adalah sebagai berikut.
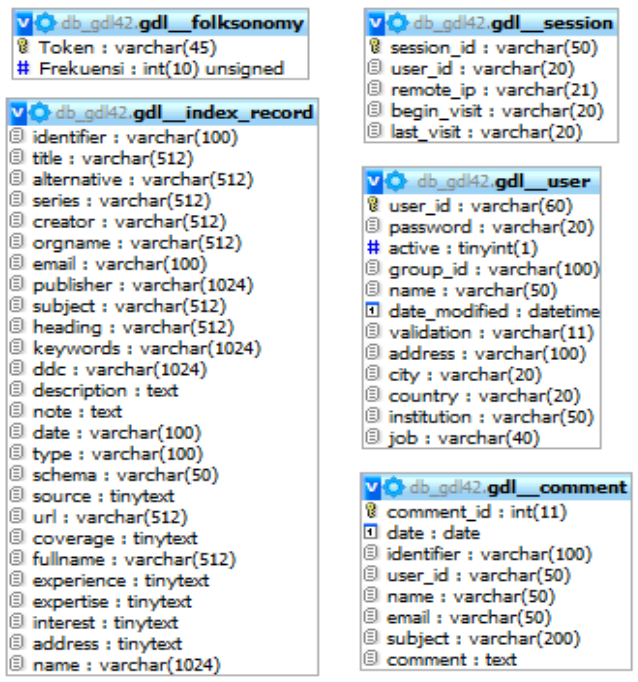

Gambar 4. Rancangan Tabel1 
Tabel folksonomy digunakan untuk menyimpan frekwensi kata-kata yang tersimpan sebagai kata kunci dalam karya ilmiah yang dimuat. Tabel index_record digunakan untuk menyimpan data indeks identitas karya ilmiah yang dimasukkan. Tabel session digunakan untuk menyimpan session pengguna yang sedang online. Tabel user digunakan untuk menyimpan data user yang terlibat dalam pengelolaan dan pemanfaatan sistem. Tabel comment digunakan untuk memberikan komentar atau topic diskusi terkait dengan karya ilmiah yang dimasukkan ke dalam sistem.

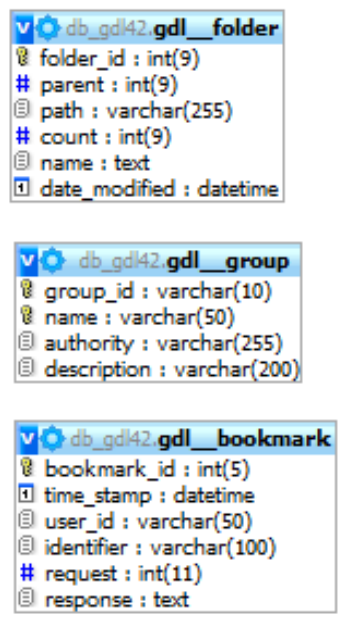

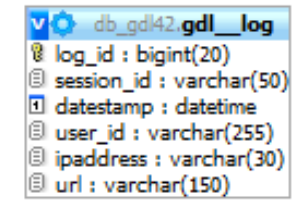

voldb_gdl42.gdl_metadata identifier : varchar(100)

\# folder : int( 9 )

path : varchar(100)

type : varchar(20)

$\mathrm{xml}$ data : text

1) date modified : datetime

owner : varchar(36)

status : varchar(8)

prefix : varchar(10)

repository : text

\section{Gambar 5. Rancangan Tabel 2}

Pada Gambar 5 terdapat rancangan tabel folder, log, group, metadata, dan tabel bookmark. Tabel folder digunakan untuk menyimpan nama folder tempat file diupload termasuk juga path dan jumlah file yang ada pada folder tersebut. Tabel group di gunakan untuk menyimpan klasifikasi pengguna yang dapat mengakses sistem. Tabel bookmark digunakan untuk menyimpan permintaan terhadap artikel tertentu oleh pengguna. Tabel log digunakan untuk menyimpan log atau catatan dari pengguna-pengguna yang pernah masuk ke dalam sistem. Tabel metadata digunakan untuk menyimpan jenis metadata yang disimpan dalam sistem.

Pengembangan aplikasi pengelolaan karya ilmiah mahasiswa dan dosen dengan menggunakan teknologi web telah berhasil dilakukan dan telah diujicobakan terbatas dengan memasukkan berbagai sumber karya akademik mahasiwa dan dosen yang telah diidentifikasi sebelumnya. Aplikasi yang telah dikembangkan telah dilakukan uji ahli untuk menilai aspek rancangan antarmuka dan efektifitas serta fleksibilitas yang ada pada aplikasi tersebut.

Aplikasi ini dikembangkan menggunakan CMS (Content Management System) Ganesha Digital Library Versi 4.2 (GDL 4.2) yang dibuat oleh KMRG ITB. Aplikasi ini dimodifikasi sedemikian rupa agar dapat disesuaikan dengan kebutuhan terkait dengan pengelolaan karya akademik mahasiswa dan dosen, yang sementara ini data-data yang sudah dimasukkan ke dalam sistem adalah data yang ada pada Jurusan Manajemen Informatika. Aplikasi yang telah dikembangkan mampu menangani masalah pengelolaan karya akademik mahasiswa dan dosen. Pengelolaan yang dimaksud adalah sebagai pengarsipan hasil-hasil karya akademik mahasiswa dan dosen. Klasifikasi dari karya akademik mahasiswa dan dosen tersebut antara lain adalah: laporan PKM, laporan PKL, laporan tugas akhir, laporan skripsi, tesis, disertasi, makalah dalam prosiding, artikel dalam jurnal, proposal penelitian dan laporan penelitian. Dimana dalam perkembangan berikutnya klasifikasi ini masih dapat dikembangkan lagi lebih luas sehingga dapat mengadopsi semua karya-karya akademik yang telah dihasilkan oleh dosen dan mahasiswa. 
Untuk menjaga agar tidak terjadi penyalahgunaan aplikasi, maka dalam sistem ini pengguna diklasifikasikan berdasarkan kapasitasnya, sebagai contoh adalah pengguna yang mengontrol dan mengelola keseluruhan sistem ini disebut sebagai administrator, kemudian pengguna yang dapat memasukkan artikel disebut sebagai editor. Agar pengguna dapat mengunduh artikel-artikel yang ada maka pengguna tersebut harus terdaftar dalam sistem dan telah disetujui oleh administrator. Sementara itu pengunjung lain yang tidak terdaftar hanya dapat melihat dan melakukan pencarian saja, agar bisa melihat karya-karya akadmeik apa saja yang ada dalam sistem.

Pada aplikasi ini telah disediakan menu pencarian untuk memudahkan pengguna dalam melihat dan mencari artikel-artikel yang diinginkan. Setiap artikel yang ditampilkan dalam aplikasi, dapat diberikan komentar kepada penulisnya sehingga itu akan sangat berguna bagi penulis yang bersangkutan untuk melihat respon yang diberikan oleh pengunjung. Dalam proses pencarian pengguna dapat memasukkan kata kunci pada kotak pencarian, atau dapat juga dilakukan dengan mengkombinasikan beberapa kata kunci yang terkait dengan artikel yang akan dicari.

Dari pembahasan yang telah dipaparkan di atas, dapat dikatakan bahwa aplikasi yang telah dikembangkan ini telah mengakomodasi semua kebutuhan terkait dengan pengelolaan karya akademik mahasiswa dan dosen. Aplikasi ini dapat juga di manfaatkan sebagai rujukan bagi mahasiswa maupun dosen dalam melakukan penelitian maupun pembuatan karya akademik lainnya. Disamping itu pula aplikasi ini dapat juga digunakan sebagai sarana untuk pengecekan kesamaan judul penelitian bagi mahasiswa maupun dosen.

\section{SIMPULAN DAN SARAN}

Berdasarkan hasil pengembangan aplikasi dan pembahasan yang telah dilakukan, maka dapat dirumuskan beberapa simpulan penelitian sebagai berikut.

Dari hasil identifikasi hasil karya ilmiah mahasiswa dan dosen di lapangan (yang ada di Jurusan Manajemen Informatika), dapat diklasifikasikan karyakarya akademik tersebut antara lain adalah: laporan PKM, laporan PKL, laporan tugas akhir, laporan skripsi, tesis, disertasi, makalah dalam prosiding, artikel dalam jurnal, proposal penelitian dan laporan penellitian

Telah digambarkan model arsitektur dan infrastruktur jaringan yang ada guna mendukung implementasi aplikasi yang telah dikembangkan

Telah di rancang konsep database yang mampu mengelola karya-karya akademik yang ada, termasuk juga bila nantinya ada pengembangan klasifikasi sumber karya akademik lain di luar dari yang sudah di identifikasi

Aplikasi yang dikembangkan telah menyediakan model pencarian dengan kata kunci tunggal maupun jamak (kombinasi beberapa kata kunci berdasarkan identitas artikel), sehingga memudahkan pengguna dalam melakukan pencarian artikel

Terkait dengan masalah security (keamanan) terhadap pengkopian teks, maka dalam system ini teks yang dapat dibaca hanya dalam bentuk abstrak nya saja, sedangkan untuk artikel lengkap dibuat dalam format gambar (jpg) yang dikompresi, dan setiap pengguna yang sudah terdaftar 
dapat mengunduhnya untuk dipergunakan lebih lanjut sebagai bahan referensi

Dalam aplikasi ini, juga disediakan fasilitas komentar dari setiap pembaca atau pengunjung terkait dengan karya ilmiah yang dimuat, sementara terkait dengan system secara keseluruhan biasa disampaikan melalui email

Telah dilakukan evaluasi atau ujicoba sistem yang telah dikembangkan, dengan melibatkan beberapa ahli dalam bidang yang sesuai, sebelum system diuji cobakan atau di implementasikan.

Saran yang dapat diberikan terkait dengan pengembangan aplikasi ini adalah perlunya dilakukan sinkronisasi database yang dapat mengintegrasikan semua sistem yang ada pada lembaga. Integrasi yang dimaksud sebagai contoh adalah diintegrasikan dengan data kepegawaian dosen, dan koleksi hasil penelitian dengan lembaga penelitian. Dengan melakukan sinkronisasi dan integrasi tersebut akan dapat dilihat dengan mudah riwayat karya akademik setiap dosen yang ada, serta penelitian-penelitian yang pernah dilakukan, yang pada akhirnya dapat digunakan sebagai penentuan kebijakan arah penelitian dosen-dosen yang ada.

\section{DAFTAR PUSTAKA}

A. A. Gede Agung. 2011. Pengembangan Model Peningkatan Profesionalisme Guru Berkelanjutan Pasca Sertifikasi Melalui Pendekatan Pengayaan Berbasis Teknologi Informasi Dan Komunikasi Di Provinsi Bali. Jurnal Penelitian dan Pengembangan Pendidikan (JPPP). Volume 5, Nomor 3, Edisi Desember 2011. pp 377-395.

Arif B. Putra N, dkk. 2010. PERANCANGAN SISTEM INFORMASI JURNAL ILMIAH DENGAN PENCARIAN BERBASIS BAHASA ALAMI. Prosiding Seminar Nasional Aplikasi
Teknologi Informasi 2010 (SNATI 2010) ISSN: 1907-5022. Yogyakarta, 19 Juni 2010.

Candiasa, I Made, dkk. 2011. Modul Hiperteks dengan Evaluasi On-line Sebagai Suplemen Pembelajaran Reguler di SMA dalam Upaya Peningkatan dan Pemerataan Mutu Pendidikan. Jurnal Penelitian dan Pengembangan Pendidikan (JPPP). Volume 5, Nomor 1, Edisi April 2011. pp 18-35.

Depri Pramana. 2010. Sistem Informasi Karya Akademik Mahasiswa Berbasis Web. Laporan Tugas Akhir pada Jurusan Manajemen Informatika. Singaraja: tidak dipublikasikan.

Didik Dwi Prasetyo. 2004. Solusi Pemrograman Berbasis Web Menggunakan PHP5. Elex Media Komputindo Kelompok Gramedia:Jakarta.

Edward Yourdon, 1989. Modern Structured Analysis. New Jersey : Prentice - Hall International, Inc.

Mulyana, 2004. Trik Membangun Situs Menggunakan PHP dan My SQL. Elex Media Komputindo Kelompok Gramedia:Jakarta.

Nugroho Bunafit, 2004. Perancangan Web dengan Fireworks dan Dreamweaver MX. Gava Media:Yogyakarta.

Rizal Fathoni Aji, 2010. PENGEMBANGAN GARUDA (GARBA RUJUKAN DIGITAL) SEBAGAI SUMBER RUJUKAN KARYA ILMIAH DI INDONESIA. Prosiding Seminar Nasional Aplikasi Teknologi Informasi 2010 (SNATI 2010) ISSN: 1907-5022. Yogyakarta, 19 Juni 2010.

Thabrani Suryanto, 2005. Web Statis dan Dinamis dengan Dreamweaver 8. Elex Media Komputindo Kelompok Gramedia:Jakarta.

Tri Susilowati, 2010. RANCANG BANGUN E-LIBRARY BERBASIS CUSTOMER RELATIONSHIP MANAGEMENT (CRM) STUDI KASUS STMIK PRINGSEWU. Prosiding Konferensi Nasional Sistem dan Informatika 
2010. ISSN:1979-9845. Bali, November 13, 2010

Veronica S. Moertini dan Tim Pelaksana Program-1, 2006. Metodologi Perancangan Master Plan Pangkalan Data untuk Mendukung Penjaminan Mutu Perguruan Tinggi. Laporan disampaikan pada Seminar Nasional Penjaminan Mutu Perguruan Tinggi dan Sistem Pangkalan Data Pendukungnya tanggal 22 Desember 2006.

Zainal Hasibuan, 2007. Kontribusi Dunia Pendidikan dalam Bidang Teknologi Informasi untuk Dunia Usaha/Industri. Makalah disampaikan pada Seminar Jurusan Manajemen Informatika tanggal 7 Mei 2007 